\title{
PENGENALAN DAN IMPLEMENTASI PERILAKU HEMAT ENERGI DI SMP PASUNDAN 1 CIMAHI
}

\author{
Arya Wulung, Purwinda Iriani, Siti Saodah, Sri Utami, Yanti Suprianti \\ Jurusan Teknik Konversi Energi, Politeknik Negeri Bandung \\ Jl. Gegerkalong Hilir, Desa Ciwaruga, Ciwaruga, Parongpong, Kabupaten Bandung Barat, Jawa Barat \\ 40012, Indonesia \\ Email: aryawulung@yahoo.com, purwinda.iriani@polban.ac.id, ssherlina@yahoo.com, \\ utamiwu@yahoo.com, yanti.suprianti@polban.ac.id
}

\begin{abstract}
ABSTRAK
Pembangunan karakter pada siswa di jenjang pendidikan menengah, merupakan salah satu dari tujuan pendidikan dasar dan menengah di Indonesia. Salah satu standar kompetensi lulusan siswa sekolah menengah pertama adalah pengembangan karakter melalui nilai-nilai pemahaman akan sikap dan tindakan yang selalu berupaya mencegah kerusakan pada lingkungan alam di sekitarnya, serta mengembangkan upaya-upaya untuk memperbaiki kerusakan alam yang sudah terjadi dan selalu ingin memberi bantuan bagi orang lain dan masyarakat yang membutuhkan. Kerusakan lingkungan yang disebabkan oleh penggunaan bahan bakar fosil dalam industri pembangkitan listrik tidak dapat dicegah karena kebutuhan listrik yang semakin meningkat. Pola konsumsi listrik sendiri dipengaruhi oleh faktor karakter dan perilaku penggunanya. Oleh karena itu dibutuhkan usaha dalam menanamkan kebiasaan bijak dalam menggunakan energi sedini mungkin kepada generasi muda. Pengembangan karakter melalui berperilaku bijak dalam penggunaan energi sendiri telah sejalan dan menunjang program penghematan energi yang dilakukan pemerintah. Melalui program pengabdian kepada masyarakat yang diselenggarakan UPPM Polban, tim P2M dari Jurusan Teknik Energi telah melakukan kegiatan sosialisasi dan kegiatan pendukung lainnya yang bertemakan perilaku hemat energi. Mitra yang terlibat adalah SMP Pasundan 1 Cimahi. Dari kegiatan pengabdian yang telah dilakukan, tahap pertama kegiatan berupa sosialisasi/workshop hidup hemat energi telah dilakukan dan mendapat respons positif. Antusiasme wakil siswa setiap kelas dan para guru serta manajemen sekolah yang hadir dan mengikuti keseluruhan kegiatan, menjadi salah satu indikator suksesnya acara. Kegiatan tahap kedua adalah melibatkan siswa dalam menumbuhkan minat untuk berperilaku hemat energi melalui pembuatan poster hemat energi. Enam poster terbaik telah dipilih dari 150 poster yang dibuat oleh siswa. Upaya lain dalam berperilaku hemat energi di lingkungan mitra adalah melalui pemasangan stiker rambu -rambu peringatan dalam perilaku hemat energi. Dari kegiatan-kegiatan tersebut dapat disimpulkan bahwa pesan berperilaku hemat dalam penggunaan energi telah sampai pada mitra dan ditanggapi positif melalui dilakukannya pemasangan rambu-rambu peringatan (stiker) di setiap area.
\end{abstract}

Kata kunci : hemat energi, sekolah menengah pertama, perilaku 


\section{PENDAHULUAN}

UU nomor 20/2003 tentang Sistem Pendidikan Nasional, Permendiknas nomor 22/2006 tentang Standar Isi, Permendiknas nomor 23/2006 tentang SKL, Inpres nomor $1 / 2010$ tentang Percepatan Pelaksanaan Prioritas Pembangunan Nasional Tahun 2010 menyatakan/menghendaki/memerintahk an pengembangan karakter peserta didik melalui pendidikan di sekolah. Salah satu bentuk pengembangan karakter adalah menanamkan pemahaman akan sikap dan tindakan yang selalu berupaya mencegah kerusakan pada lingkungan alam di sekitarnya, serta mengembangkan upaya-upaya untuk memperbaiki kerusakan alam yang sudah terjadi dan selalu ingin memberi bantuan bagi orang lain dan masyarakat yang membutuhkan.Berperilaku bijak dalam penggunaan energi merupakan salah satu implementasi dari upaya memperbaiki kerusakan alam.

Dalam rangka menunjang program penghematan energi, pemerintah, dalam hal ini Kementerian ESDM, melalui Direktorat Jenderal Energi Baru Terbarukan dan Konservasi Energi (EBTKE) telah menyelenggarakan Home and School Energy Efficiency Champion (HSEEC) pada tahun 2013 dan 2014, dan kemungkinan akan menjadi agenda rutin setiap tahun. Program ini dapat diikuti oleh sekolahsekolah dan rumah, dalam hal ini diwakili oleh siswa, yang dalam kurun waktu tertentu (beberapa bulan) melakukan aktivitas-aktivitas penghematan energi dan memonitor serta melaporkan konsumsi energinya ke panitia lomba.

Untuk mensinergikan program Ditjen EBTKE mengenai penghematan energi dengan cita-cita pendidikan nasional dalam hal pembentukan karakter baik pada siswa, maka melalui program pengabdian kepada masyarakat yang diselenggarakan di UPPM Polban, Tim Pengabdian Masyarakat di Jurusan Teknik Konversi Energi Polban mengusulkan kegiatan terkait tema berperilaku hemat energi di lingkungan sekolah.

\section{Profil SMP Pasundan 1 Cimahi}

SMP Pasundan 1 Cimahi beralamat di Jl. Ciawitali No. 162 RT/RW: 007/009 Kel. Citeureup Kec. Cimahi Utara 40512 Kota Cimahi. Sekolah ini menempati lahan seluas $2.159 \mathrm{~m}^{2}$, dan dibangun dalam susunan dua lantai demi memenuhi kebutuhan akan siswa pendaftar yang semakin banyak. Saat ini, siswa SMP Pasundan 1 Cimahi terbagi ke dalam 30 rombongan belajar yang tersebar di kelas VII, VIII, dan IX. Walaupun berstatus sebagai sekolah swasta, namun sekolah ini telah memiliki akreditasi baik "A", dan memiliki populasi terbesar ke-2 di wilayah Kota Cimahi, yatu 1.192 siswa (data tahun ajaran 2014/2015).

Untuk menunjang kegiatan belajar mengajar, SMP Pasundan 1 Cimahi yang dikepalai oleh Dra. Hj. Yuyum, S.P., M.M. inimemiliki 39 orang guru dengan pendidikan terakhir D3 hingga S3. Jumlah tersebut dipertahankan untuk juga memenuhi kewajiban 24 jam mengajar per minggu yang dipersyaratkan untuk menunjang kinerja guru dalam kaitannya dengan sertifikasi guru.

Fasilitas yang dimiliki untuk sarana pengajaran adalah 20 ruang kelas yang sebagian besar dalam kondisi baik, ruang penunjang lainnya yang terdiri atas perpustakaan, laboratorium IPA, ruan keterampilan, ruang multimedia, ruang kesenian dan laboratorium bahasa. Sementara untuk menunjang keperluan manajemen sekolah, 
dilengkapi pula dengan ruang kepala sekolah, ruang wakil kepala sekolah, ruang guru, dan ruang tata usaha.Dan untuk menunjang kebutuhan, kreatifitas dan sisi spiritual siswa, disediakan pula ruang OSIS, ruang PMR/Pramuka, koperasi, hall, ruang UKS, ruang $\mathrm{BK}$, gudang, kantin, dan mushola (ruang ibadah).

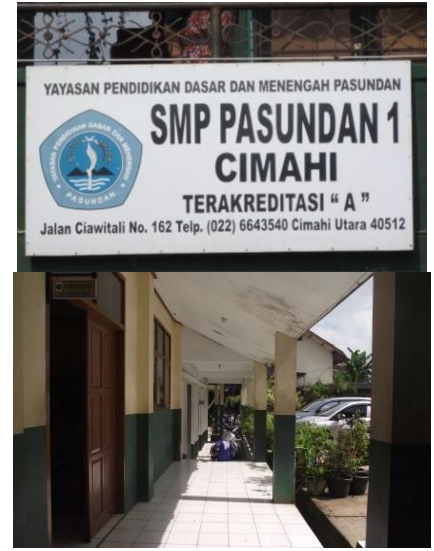

Gambar 1. Kondisi Umum SMP Pasundan 1 Cimahi

\section{Kondisi dan Permasalahan di SMP Pasundan 1 Cimahi}

Beberapa permasalahan umum yang menjadi kendala perkembangan sekolah, di antara permasalahan umum yang ditemui adalah sebagai berikut:

a. SMP Pasundan 1 Cimahi berdiri di atas lahan seluas $2.159 \mathrm{~m}^{2}$, dengan kapasitas siswa yang dapat ditampung hanya sebanyak 1200 orang. Minat siswa baru yang ingin bersekolah disini semakin meningkat tiap tahunnya. Dan hal tersebut menjadi peluang pihak sekolah untuk mengembangkan fasilitas ruangan yang ada. Namun hal tersebut terkendala oleh keterbatasan lahan, sehingga bantuan pemerintah tidak dapat diambil (karena bantuan lebih menekankan pada penambahan ruangan, bukan pada perluasan lahan). b. Minat belajar siswa masih rendah. Hal ditunjukkan dengan rendahnya nilai $\mathrm{UN}$ rata-rata yang masih rendah, tercatat 5,52 untuk tahun ajaran 2013/2014 (Profil SMP Pasundan 1 Cimahi, 2014).

c. Pada sesi konseling siswa, guru/wali kelas menghadapi kesulitan dalam berkomunikasi dengan orang tua/wali murid, karena kesibukannya bekerja untuk memenuhi kebutuhan hidup (rata-rata tingkat ekonomi orang tua siswa adalah menenga ke bawah).

d. Kebersihan lingkungan sekolah belum terjaga. Hal ini ditunjukkan oleh masih adanya sampah yang tidak dibuang pada tempat sampah, dan toilet yang kurang layak pakai.

e. SMP Pasundan 1 Cimahi belum pernah mendapatkan pemaparan mengenai perilaku hemat energi dari pihak yang berkompeten.

\section{Permasalahan spesifik}

Dari permasalahan yang dipaparkan pada subbab sebelumnya, poin mengenai perilaku hemat energi yang belum pernah diterima oleh pihak sekolah merupakan permasalahan yang paling diprioritaskan dan sesuai dengan bidang keenergian yang diusung oleh Tim Pengabdian Masyarakat Jurusan Teknik Konversi Energi Polban.

Hasil kunjungan ke SMP Pasundan 1 Cimahi yang dilakukan oleh dosen Jurusan Teknik Konversi Energi pada awal bulan Juni 2015 menunjukkan beberapa hal sebagai berikut:

1. Sekolah dilengkapi dengan peralatan yang mengkonsumsi energi listrik cukup besar, yaitu

a. lab bahasa yang alih fungsi menjadi ruangan 
DIFUSI,

Volume 1, No.1, Januari 2018

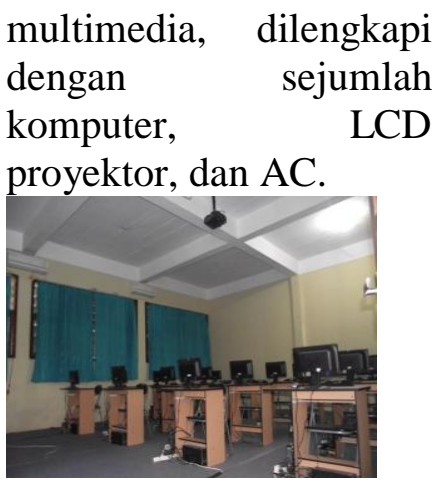

Gambar 2. Laboratorium Bahasa/Ruang Multimedia

b. tersedia penampung air, yang menggunakan pompa untuk mengambil air tanah

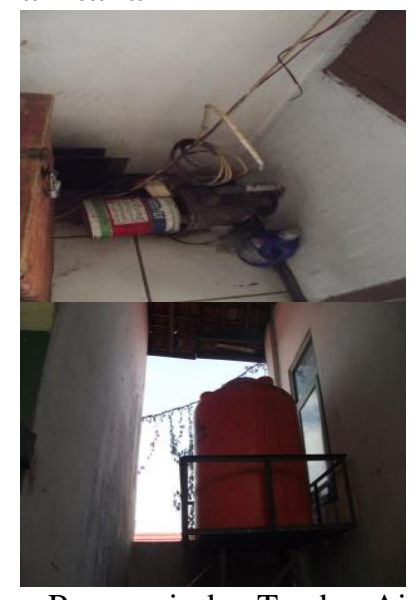

Gambar 3. Pompa air dan Tandon Air

2. Banyak ruangan yang tidak memiliki akses terhadap pencahayaan alami (matahari), sehingga memerlukan penerangan lampu.

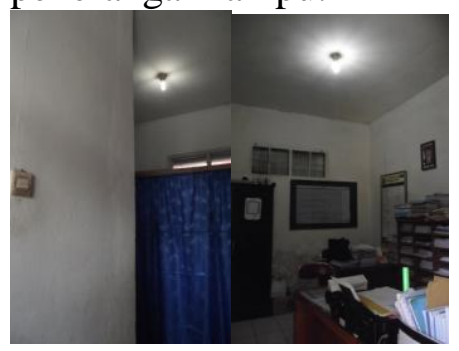

Gambar 4. Penerangan dengan Lampu di beberapa Ruangan

3. Lampu tetap menyala di ruangan yang tidak digunakan.

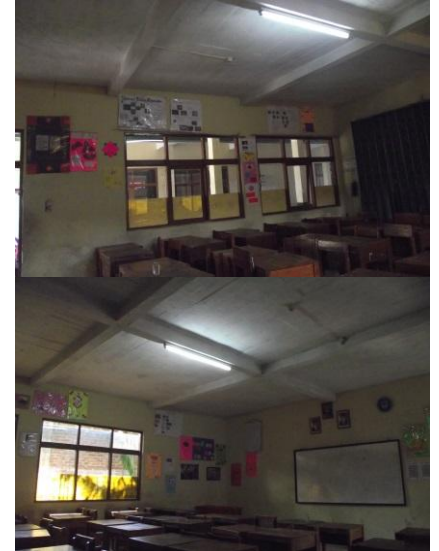

Gambar 5. Pencahayaan di Ruang Kelas

4. Tidak adanya himbauan untuk penghematan energi listrik di sekitar sumber listrik ataupun saklar.

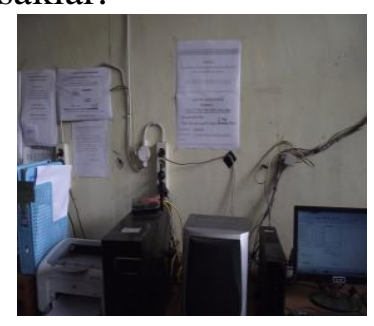

Gambar 6. Tidak ada Himbauan di Sekitar Saklar

5. Tidak adanya himbauan untuk penghematan air, baik di toilet siswa maupun di toilet guru. Pengambilan air sendiri menggunakan energi listrik (pompa).

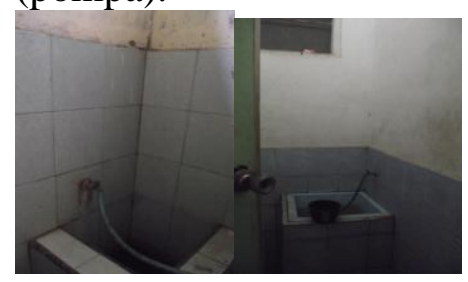

Gambar 7. Toilet Siswa dan Guru

Melihat kondisi SMP Pasundan 1 Cimahi dari hasil kunjungan yang telah dilakukan, Tim Pengusul semakin yakin bahwa permasalahan mengenai berperilaku hemat energi belum disadari sepenuhnya oleh pihak sekolah SMP Pasundan 1 Cimahi. 


\section{METODE}

Kegiatan Pengabdian Masyarakat di lingkungan SMP Pasundan 1 Cimahi adalah berangkat dari pendekatan hasil analisis situasi yang dijumpai dan disepakati oleh Mitra sebagai bentuk solusi yang ditawarkan (Gambar 1).

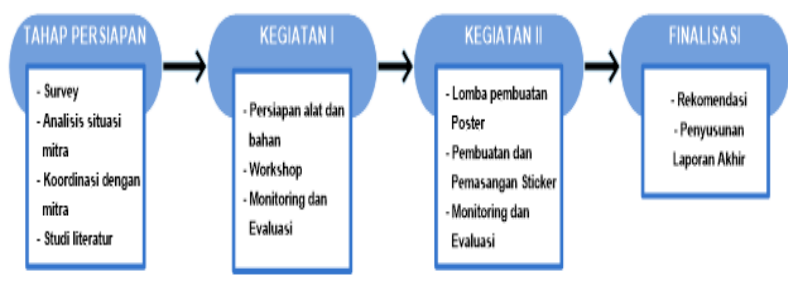

Gambar 8. Metode Pelaksanaan Pengabdian Masyarakat di SMP Pasundan 1 Cimahi

A. Tahap Persiapan

Pada tahap ini terdapat beberapa kegiatan yang dilakukan, yaitu:

1) Survey

Tim pengabdian masyarakat melakukan visitasi ke lapangan, yakni SMP Pasundan 1 Cimahi untuk memperoleh informasi mengenai profil sekolah, kondisi gedung, ruang kerja dan ruang belajar siswa, data mengenai konsumsi energi per bulan, dan informasi lainnya yang terkait dengan situasi sekolah. Informasi yang akan diperoleh, didapat memalui metode wawancara dengan pihak guru, siswa, dan staf sekolah. Untuk dapat memperoleh profil konsumsi energi listrik, dilakukan interview untuk memperoleh data sekunder konsumsi listrik dan air per bulan. Dilakukan pula inventarisasi peralatan yang mengkonsumsi energi listrik cukup besar. Dari hasil analisis yang diperoleh, maka ditentukan pemilihan masalah yang telah dijustifikasi oleh mitra.
2) Koordinasi dengan Mitra

Hasil justifikasi permasalahan telah disepakati oleh mitra dan perumusan serta penentuan tujuan kegiatan pengabdian dapat dibuat. Dari hal tersebut muncul bentuk-bentuk solusi yang ditawarkan oleh tim P2M Jurusan Teknik Konversi Energi (JTKE) yaitu workshop, lomba pembuatan poster, pemasangan sticker/tanda, dan monitoring serta evaluasi kegiatan. Bentuk-bentuk solusi yang ditawarkan tersebut, tentunya memerlukan koordinasi dengan mitra agar tujuan kegiatan P2M tercapai.

3) Studi Literatur

Tim P2M JTKE melakukan penelusuran referensi yang berkaitan dengan upaya-upaya konservasi energi yang dicanangkan Pemerintah pada lingkup kegiatan masyarakat, khususnya yang terkait di lingkungan pendidikan dasar (Sekolah Menengah Pertama). Selain itu dibutuhkan studi literature mengenai bagaimana menumbuhkan pemahaman dan kesadaran dalam berperilaku pada anak usia 13-15 tahun, melalui kegiatan-kegiatan yang ditawarkan kepada pihak sekolah.

B. Kegiatan Pertama (I)

Pada kegiatan pertama (I) ini terdapat beberapa tahapan, antara lain:

1) Persiapan Alat dan Bahan

Tim P2M JTKE dan mitra saling berkoordinasi mengenai persiapan pelaksanaan kegiatan pengabdian yang berkaitan dengan sarana prasarana yang dibutuhkan dan supporting tools yang dibutuhkan selama kegiatan P2M berlangsung. 
2) Workshop

Tim P2M JTKE akan memberikan sosialisasi mengenai pengenalan terhadap perilaku yang terkait dengan penghematan penggunaan energi. Luaran dari kegiatan ini adalah modul workshop mengenai hemat energi.

3) Monitoring dan Evaluasi

Tahap pemantauan dari hasil kegiatan workshop yang telah dilakukan, dimana indicator keberhasilan kerja dapat dilihat dari sejauh mana siswa dan guru telah mengetahui dan memahami perilaku hemat energi di lingkungan sekolah, melalui questioner yang diberikan tim P2M JTKE. Selain itu juga dilakukan interview kepada beberapa siswa dan guru terkait dengan dampak yang diterima selama mengikuti kegiatan workshop.

C. Kegiatan Kedua (II)

1) Lomba Pembuatan Poster

Upaya pengenalan dan pemahaman siswa terhadap perilaku hemat energi dilakukan melalui media seni visual. Lomba pembuatan poster hemat energi akan menghasilkan 5 pemenang utama. Sebagai bentuk apresiasi terhadap karya yang dibuat siswa, maka poster-poster hemat energi tersebut akan dipajang di dalam kelas sebagai reminder bagi seluruh siswa.

2) Pembuatan dan Pemasangan Stiker

\section{HASIL DAN PEMBAHASAN}

\section{Kegiatan Tahap I}

Inti kegiatan tahap pertama adalah sosialisasi/workshop yang dilaksanakan pada tanggal 10 September 2015 di ruang serba guna SMP Pasundan 1 Cimahi dan
Upaya reminding dalam berperilaku hemat energi di lingkungan sekolah dilakukan dengan memasang sticker yang berhubungan dengan penggunaan energi secara bijak, seperti mematikan lampu bila tidka digunakan, bijak dalam menggunakan air, dan lain-lain. Sticker hemat energi akan disediakan tim P2M JTKE dan dipasang bersama-sama oleh siswa dan guru di area-area tertentu.

3) Monitoring dan Evaluasi

Tahap monitoring mengenai penggunaan listrik sekolah sebelum dan sesudah kegiatan workshop dan lainnya dilakukan (3 bulan) akan dievaluasi melalui tagihan listrik dan air pihak sekolah. Selain itu monitoring juga dilakukan per minggu oleh guru/wali kelas melalui form ceklis :

a) mematikan lampu jika tidak digunakan

b) mematikan kran air

c) mematikan komputer di lab

d) mematikan $\mathrm{TV}$

e) mematikan $\mathrm{AC}$

f) mematikan dispenser, dll

D. Finalisasi

Pada tahap ini tim P2M JTKE akan memberikan rekomendasi kepada pihak sekolah terkait upaya-upaya konservasi energi yang dapat dilakukan. Rekomendasi tersebut lebih ditekankan kepada upaya manajemen energi terhadap unit dan penggunaan alat elektronik.

dihadiri oleh para siswa, guru, serta staf SMP Pasundan 1 Cimahi. Tema yang diambil adalah "Hidup Hemat Energi di Lingkungan SMP Pasundan 1 Cimahi“. 

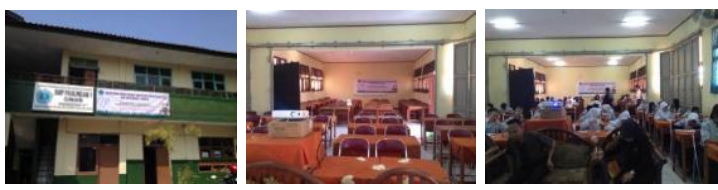

Gambar 9. Sosialisasi kegiatan workshop hemat energi di lingkungan SMP Pasundan 1 Cimahi: spanduk sosialisasi (kiri), persiapan (tengah), dan kegiatan workshop (kanan).

Pada awal acara sosialisasi diberikan terlebih dahulu kuesioner untuk mengukur pemahaman para peserta workshop. Peserta workshop, baik siswa mupun guru mengisi kuesioner yang dibagikan oleh panitia.

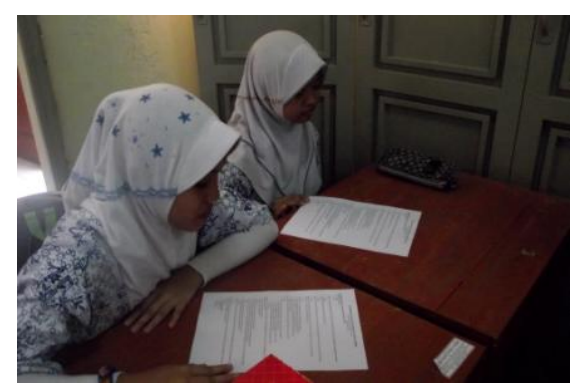

Gambar 10. Kegiatan Pengisian Kuesioner Hemat Energi

Hasil penelusuran pemahaman perilaku hemat eneri adalah sebagai berikut:

1. Saat ini telah berada pada kondisi krisis energi, direspon setuju oleh $81,02 \%$ responden, tidak setuju sebanyak $12,03 \%$ dan sisanya tidak mengisi.

2. Pentingnya penghematan energi, direspon dengan jawaban "Ya" oleh seluruh responden.

3. Kesempatan yang dimiliki untu menurunkan penggunaan energi di rumah atau sekolah, direspon memiliki kesempatan oleh $95,74 \%$ responden, tidak memiliki kesempatan oleh $4,51 \%$ responden dan sisanya tidak mengisi.

4. Jika Anda harus memantau penggunaan energi di rumah, apakah membantu bila Anda sadar mengenai pentingnya penghematan energi? Hal ini terkait dengan tanggung jawab terhadap pemantauan penggunaan energi di rumah. Pertanyaan ini direspon "Ya" oleh 96,99\% responden, "Tidak" oleh 1,5\% responden, dan sisanya tidak mengisi.

5. Cara-cara menghemat energi, telah diketahui oleh sebagian besar responden, dan dipilah menjadi $33,83 \%$ mengetahui banyak cara penghematan, $35,34 \%$ menyatakan mengetahui 3-4 cara, 6,32\% mengetahui cara dasar/basic saja, dan sisanya tidak mengetahui.

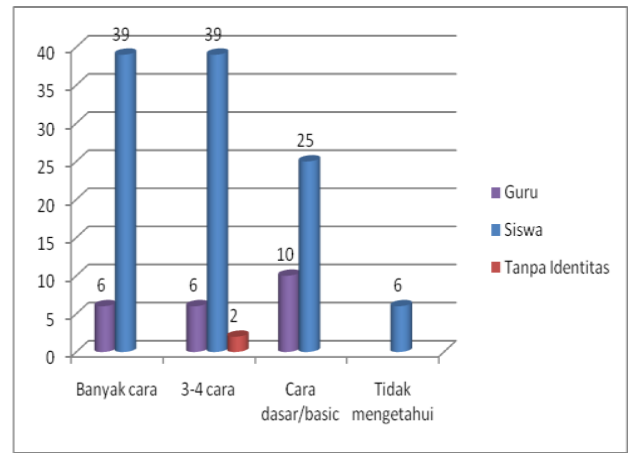

Gambar 11. Jawaban responden terhadap pertanyaan no. 5

6. Aspek pengamalan dari teknik penghematan yang telah diketahui, ternyata telah dipraktikkan oleh sebagian besar responden di rumahnya masing-masing, yaitu sebesar 94,74\%, dengan rincian perilaku seperti ditunjukkan pada Gambar 4.

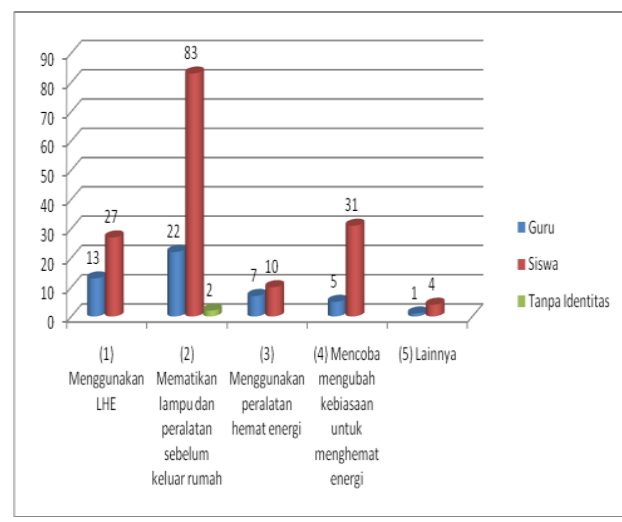

Gambar 12. Jawaban responden terhadap pertanyaan no. 6 
7. Hal yang memotivasi responden untuk mengubah perilaku untuk menurunkan penggunaan energi disebabkan oleh alasan yang berbeda, yaitu $62,5 \%$ karena peningkatan biaya energi, $28,47 \%$ karena alasan terkait kelestarian lingkungan, dan 9,03\% karena hal lain. Melihat respon tersebut, motivasi ekonomi merupakan hal yang mendominasi motivasi tersebut.

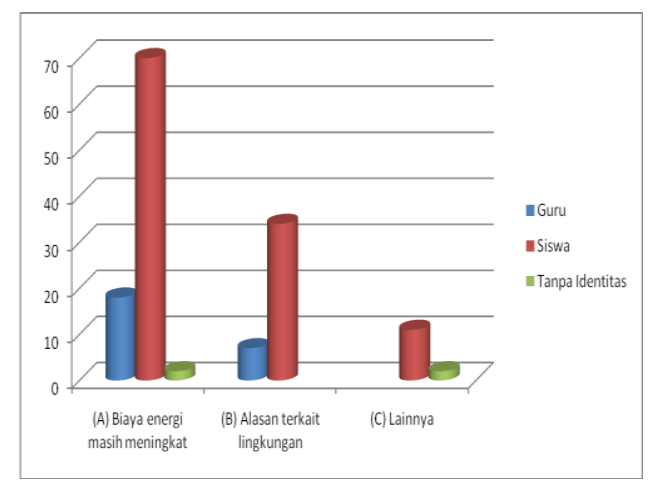

Gambar 13. Jawaban responden terhadap pertanyaan no. 7

8. Pengukuran atas sikap responden terhadap penghematan energi menunjukkan hasil sebagai berikut: a) Sikap positif dan aktif dalam menghemat energi serta keyakinan bahwa aksinya dapat memberi perubahan dinyatakan oleh $42.42 \%$ responden, b) $9.09 \%$ responden menyatakan sikap positif dan sadar, namun kegiatan hemat energi belum menjadi budaya di tempat kerja ataupun sekolah, c) responden yang belum memiliki kesadaran penuh atas penghematan energi, dan melakukannya hanya pada kondisi tertentu adalah sebesar $12.12 \%$, dan d) $36.36 \%$ menyatakan sikap netral, yaitu terkadang mencoba menghemat energi. Distribusi sikap ini memiliki distribusi parabola terbalik, dimana sikap yang terbaik dan terburuk cukup mendominasi. Namun demikian, responden dengan sikap yang terbaik, yaitu positif dan aktif menghemat energi lebih banyak dibandingkan dengan responden dengan sikap netral.

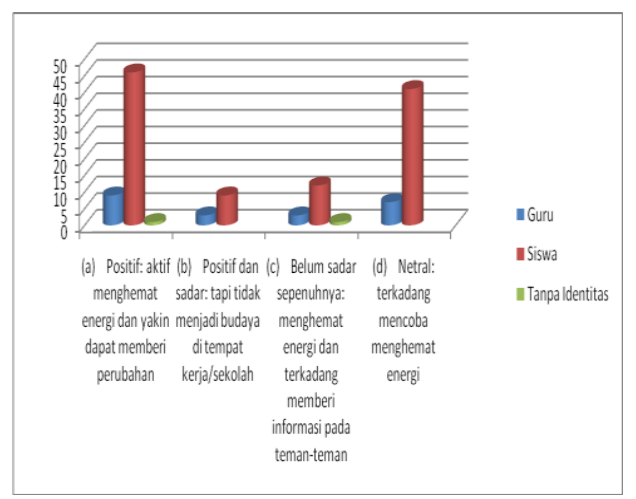

Gambar 14. Jawaban responden terhadap pertanyaan no. 8

9. Sejalan dengan sikap positif yang mendominasi di pertanyaan sebelumnya, maka untuk aspek keinginan untuk berpartisipasi dalam aktivitas penghematan energi disambut dengan respon yang sangat baik, dimana 99,25\% responden menyatakan kesediannya, dan hanya satu orang siswa yang belum memiliki keinginan untuk berpartisipasi. Hal ini semoga dapat digugah dengan sosialisasi yang akan diselenggarakan.

10. Pernyataan yang mengukur kebiasaan hemat energi di luar rumah menyatakan bahwa responden belum melakukannya secara istiqomah, terlihat bahwa pada gambar, didominasi oleh aksi yang dilakukan secara "kadang-kadang". Distribusi kontinyuitas pelaksanaan hemat energi adalah sebagai berikut: $18.80 \%$ responden menyatakan terbiasa melakukan penghematan, $5.26 \%$ menyatakan jarang, $57.14 \%$ menyatakan kadang-kadang melakukan, $15.79 \%$ selalu melakukan penghematan, dan $3.01 \%$ tidak pernah melakukan penghematan energi. 


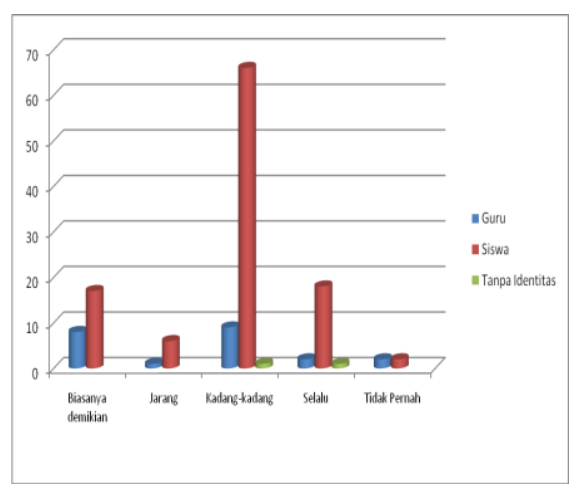

Gambar 15. Jawaban responden terhadap pertanyaan no. 10

Melalui kegiatan sosialisasi perilaku hemat energi ini, diharapkan dapat menggugah dan mendorong sikap serta aksi positif yang kontinyu dalam melakukan penghematan energi, baik di rumah maupun di sekolah.

Kegiatan workshop dimulai secara resmi dengan pemberian kata sambutan dari pihak mitra dan panitia tim P2M JTKE, serta penyerahan cendera mata (Gambar $8)$.

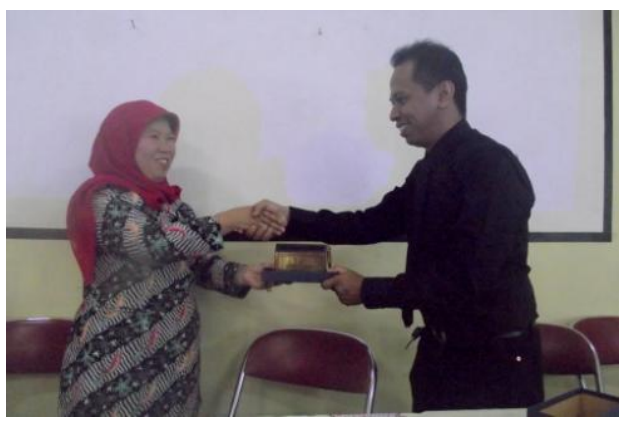

Gambar 16. Penyerahan Cinderamata dari Ketua Tim P2M JTKE kepada Kepala Sekolah SMP Pasundan 1 Cimahi

Materi yang diberikan pada kegiatan workshop ini berkenaan dengan hemat energi dan materi tambahan mengenai renewable energy.

Pada kegiatan P2M ini tidak hanya melibatkan tenaga pendidik JTKE, namun turut juga mengikutsertakan mahasiswa JTKE. Pemberian materi hemat energi disampaikan oleh mahasiswa dan dosen JTKE, dan diikuti secara antusias oleh peserta workshop yang dapat dilihat dari diskusi aktif (Gambar 9).
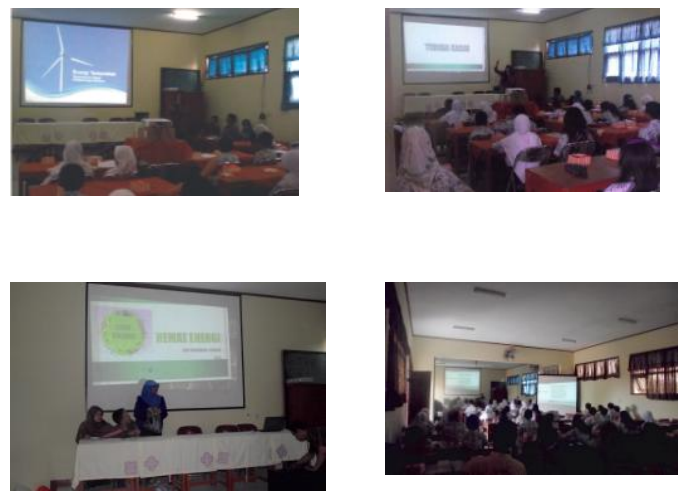

Gambar 17. Pemaparan Materi Workshop Hidup hemat Energi

\section{Kegiatan Tahap II}

Media penyampaian mengenai pengetahuan hidup dengan hemat energi tidak hanya dilakukan melalui kegiatan workshop, namun juga melalui bentuk lain yakni pembuatan poster hemat energi. Melalui media seni visual tersebut, diharapkan pengenalan dan pemahaman siswa terhadap perilaku hemat energi dapat lebih mudah. Sosialisasi lomba pembuatan poster dilakukan pada saat workshop dan juga penempelan poster yang berisi pengumuman lomba tersebut.

Pemenang utama lompa poster hemat energi sebanyak 6 orang, yang disaring terlebih dahulu oleh pihak mitra, dan dilanjutkan oleh panitia P2M JTKE. Dari 150 poster yang diterima oleh pihak mitra, terdapat 12 poster yang direkomendasikan mitra untuk dinilai dan dipilih oleh panitia P2M JTKE sebagai pemenangnya (Gambar 10). Sebagai bentuk apresiasi terhadap karya yang dibuat siswa, maka poster-poster hemat energi tersebut dipajang di dalam kelas sebagai reminder bagi seluruh siswa. Pemenang lomba poster mendapatkan hadiah berupa plakat, tas sekolah, unit portable solar kit, dan peralatan tulis (Gambar 11). 


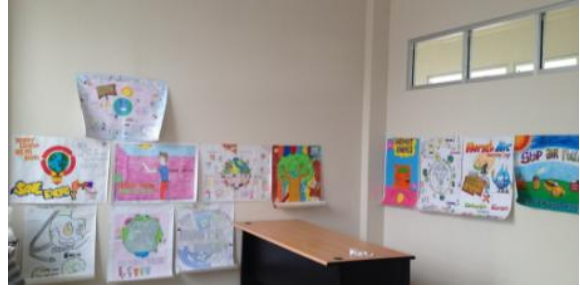

Gambar 18. Proses seleksi pemenang poster hemat energi

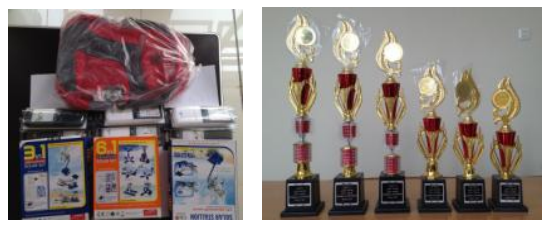

Gambar 19. Hadiah dan piala pemenang lomba poster

\section{Pembuatan dan pemasangan sticker}

Pada kegiatan ini turut dilakukan upaya reminding dalam berperilaku hemat energi di lingkungan sekolah dengan memasang sticker yang berhubungan dengan penggunaan energi secara bijak, seperti mematikan lampu bila tidak digunakan, bijak dalam menggunakan.
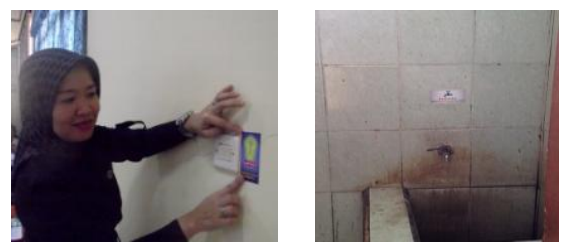

Gambar 20. Pemasangan Sticker Hemat Energi oleh Pihak Sekolah (kiri) dan Sticker Hemat Penggunaan Air (kanan)

Implementasi dari hasil workshop hemat energi di lingkungan SMP Pasundan 1 Cimahi, dilaksanakan oleh para siswa serta staf sekolah lainnya dan dimonitor langsung oleh para guru. Berdasarkan hasil wawancara dengan guru dan staf sekolah, berikut adalah bentuk dari beberapa implementasi kegiatan hemat energi di lingkungan sekolah :

Penggunaan lampu di ruang kelas hanya dilakukan selama jam belajarmengajar berlangsung. Pada beberapa ruang kelas yang terkena pencahayaan alami cukup banyak, lampu hanya digunakan ketika cuaca sedang mendung.

Penggunaan Air Conditioner (AC) di laboratorium multimedia sudah sesuai dengan rekomendasi yang diberikan yakni hanya pada saat ruang tersebut digunakan oleh siswa dan selama penggunaannya ruangan tidak dibiarkan terbuka lama dengan lingkungan luar. Penggunaan AC juga dilakukan pada ruangan Kepala Sekolah, namun pemakaiannya tidak setiap waktu dan sering digantikan oleh kipas angin.

$\checkmark$ Pada penggunaan air, baik pada kamar kecil untuk siswa maupun staf sekolah, menunjukkan pemakaian air yang relatif sesuai dengan kebutuhan. Bak penampung air pada kamar mandi tidak dibiarkan hingga tumpah dan kran air hanya dibuka saat sedang digunakan. Pada penggunaan air di kamar kecil siswa, ada beberapa saat kran air sempat tidak dimatikan setelah digunakan. Namun hal tersebut sempat diketahui oleh staf sekolah yang kemudian mematikan kran air tersebut.

$\checkmark$ Alat-alat pengkonsumsi listrik lainnya seperti komputer, printer, dispenser, pompa, dan lainnya, pada umumnya digunakan hanya pada waktu jam operasi sekolah (kecuali dispenser). Pada pengguna komputer oleh siswa di lab multimedia, proses on-and-off komputer hanya dilakukan satu kali selama berlangsungnya praktikum. Namun pada komputer staf pengajar, beberapa masih ada yang belum menggunakan standby-mode dalam penggunaannya yang diselang oleh jam mengajar atau kegiatan lain. Walaupun demikian, selebihnya staf pengajar telah menerapkan penggunaan komputer yang disesuaikan dengan situasi dan kondisi 
saat bekerja (apakah computer harus dimatikan atau cukup dalam keadaan standby).

Kegiatan pengumuman pemenang lomba poster hemat energi dilakukan pada tanggal 2 November 2015 pada saat upacara bendera. Pada kegiatan tersebut, tim P2M JTKE mengumumkan keenam pemenang lomba poster yang terdiri dari juara Harapan 1-3 dan juara 1-3 (Gambar 19). Kegiatan lomba pembuatan poster tersebut diharapkan dapat membawa siswa untuk lebih meningkatkan kesadaran terhadap pentingnya berperilaku hemat energi.

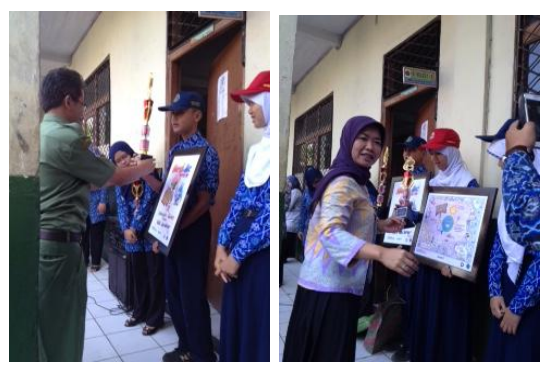

Gambar 21. Penyerahan Poster Pemenang, Piala, dan Hadiah kepada Para Pemenang

Dampak dari kegiatan P2M JTKE bersama mitra dapat ditelusuri melalui pola pemakaian listrik di lingkungan mitra dari bulan September hingga November 2015.

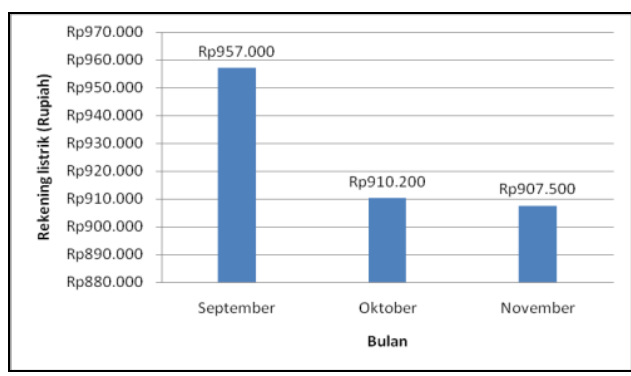

Gambar 22. Grafik Rekening Listrik Mitra Bulan Septermber hingga November 2015

Pada Gambar 14 diperoleh bahwa rekening listrik mitra di bulan September adalah $\mathrm{Rp}$ 957.000 dan setelah itu mengalami penurunan hingga bulan November yaitu menjadi $\mathrm{Rp}$ 905.000. Berdasarkan penggunaannya, selama 3 bulan telah terjadi penurunan pemakaian listrik hingga $45 \mathrm{kWh}$.

\section{Rekomendasi (Tahap Final)}

Pada tahap ini tim P2M JTKE memberikan rekomendasi kepada pihak sekolah terkait upaya-upaya konservasi energi yang dapat dilakukan. Rekomendasi tersebut lebih ditekankan kepada upaya manajemen energi terhadap unit dan penggunaan alat elektronik, yakni:

Penggunaan cahaya alami sebagai penerangan ruangan/kelas telah dilakukan oleh pihak sekolah. Upaya lain yang dapat dilakukan adalah dengan mengganti layout ruangan yang menghasilkan pencahayaan alami lebih terang.

Umumnya jenis lampu yang digunakan di ruangan kelas SMP Pasundan 1 Cimahi adalah lampu TL. Pada prinsipnya lampu tersebut dapat digunakan dengan baik sebagaimana fungsinya. Namun penggunaan daya lampu TL (umumnya 36 Watt). Penggunaan daya yang lebih kecil dengan tingkat pencahayaan yang tidak jauh berbeda dapat dihasilkan pula dari lampu LHE (Lampu Hemat Energi) dengan daya yang lebih kecil (5 atau 10 Watt)

Pada lab multimedia terdapat \pm 30 unit PC (Personal Computer) dimana masing-masing memiliki daya pemakaian sekitar \pm 500 Watt/jam. Pemakaian daya listrik terbesar adalah pada saat pertama kali PC dinyalakan. Apabila penggunaan $\mathrm{PC}$ ada pada dua sesi (kelas), maka PC tidak perlu dimatikan (shut down). PC cukup pada mode stand-by/sleep/hibernate, yang dapat menghemat penggunaan listrik hingga $0,372 \mathrm{kWh}$ per hari.

Penggunaan air harus lebih bijaksana mengingat penyediaannya menggunakan pompa listrik. 
$>$ Pemasangan colokan listrik (khususnya komputer) pada stecker listrik tidak boleh melebihi kapasitas dan harus menyesuaikan dengan besar tahanan stecker.

\section{KESIMPULAN}

Kegiatan pengabdian kepada masyarakat yang dilakukan antara Jurusan Teknik Konversi Energi dan mitra SMP Pasundan 1 Cimahi menghasilkan beberapa output dan luaran, yakni :

1. Workshop dengan tema "Hidup Hemat Energi Energi Di Lingkungan SMP Pasundan 1 Cimahi“. Pelaksanaan kegiatan berlangsung lancar dan diikuti oleh perwakilan siswa di setiap kelas dan tenaga pengajar. Materi mengenai berperilaku hemat dengan energi dan materi mengenai renewable energy, disampaikan dengan baik dan direspons dengan antusias oleh peserta workshop.

2. Pelaksanaan lomba pembuatan poster hemat energi diikuti oleh 150 peserta dengan menghasilkan 6 pemenang. Keseluruhan poster yang dibuat oleh siswa-siswi SMP Pasundan 1 Cimahi mengandung pesan ajakan/himbauan dalam berperilaku bijak terhadap penggunaan energi. Hal tersebut menunjukkan pemahaman siswa akan hemat energi telah tercapai.

3. Pemasangan sticker dengan pesan yang berisi anjuran dalam menggunakan energi secara bijak (mematikan lampu, mematikan peralatan elektronik yang tidak sedang digunakan, dan lain-lain), telah dipasang berdasarkan peruntukkannya. Upaya yang dilakukan mitra di dalam lingkungan sekolah merupakan bentuk komitmen mitra dalam mendukung program penghematan energi.

4. Implementasi perilaku hemat energi di lingkungan mitra setelah program P2M JTKE dilaksanakan terlihat melalui penggunaan listrik bulanan yang baru berlangsung 3 (tiga) bulan, yakni di September, Oktober, dan November. Penggunaan listrik di lingkungan mitra dapat turun hingga $45 \mathrm{kWh}$..

\section{REFERENSI}

Direktorat Pembinaan Sekolah Menengah Pertama, 2010-2011

- Data Penggunaan Energi, Statistik PLN, 2013

- Borang Profil SMP Pasundan 1 Cimahi, 2013 